\title{
An iterative approach to higher polyquinanes
}

\author{
Sambasivarao Kotha* and Rallapalli Sivakumar \\ Department of Chemistry, Indian Institute of Technology-Bombay, 400076, India \\ E-mail: srk@chem.iitb.ac.in
}

\section{This paper is dedicated to Prof. S. Swaminathan on the occasion of his $\mathbf{8 0}^{\text {th }}$ birthday \\ (received 26 Jun 04; accepted 05 Nov 04; published on the web 12 Nov 04)}

\begin{abstract}
A simple cyclopentane annulation strategy has been developed using inexpensive reagents. Starting from the readily available bicyclo[3.3.0]octane system several polyquinanes were prepared by iterative annulation procedure and herein we report a short and a convenient route to a new $\mathrm{C}_{20}$-hexaquinane system.
\end{abstract}

Keywords: Polyquinanes, polycyclic aliphatic compounds, hydrogenation, Grignard reactions

\section{Introduction}

Several strategies for the synthesis of polycyclopentanoids ${ }^{1-3}$ were pursued over the last two decades due to their intricate structural properties. Recently, Mehta ${ }^{4}$ proposed that polyquinane 1 may adopt a helical or a loop-like shape. To assemble such compounds, iterative cyclopentane annulation strategy is an attractive option.

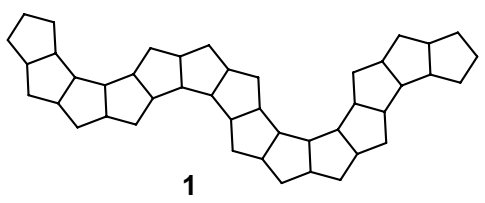

In our studies directed towards the synthesis of $\mathbf{1}$, we considered $\mathbf{2}$ as a potential precursor which could be prepared utilizing two directional synthesis ${ }^{6 a}$ starting from dione 4 involving the intermediate 3 (Figure 1). At each stage, the reactions that are to be executed in a two-fold manner would drastically reduce the number of steps to acquire a novel polycyclopentanoid framework 2. Further, the symmetry profile has been maintained throughout the synthetic strategy which inturn simplifies the spectral data. The easy accessibility of hexaquinane 2 that is suitably functionalized, with cis fused ring junction, would open up new avenues for further synthetic exploration towards the target molecule 1. Although hexaquinane of type 2 with a 
different disposition of the carbonyl groups was prepared using protective group strategy, unwanted interactions between the carbonyl and the methylene groups would prevent its elaboration to higher polyquinanes. ${ }^{6}$

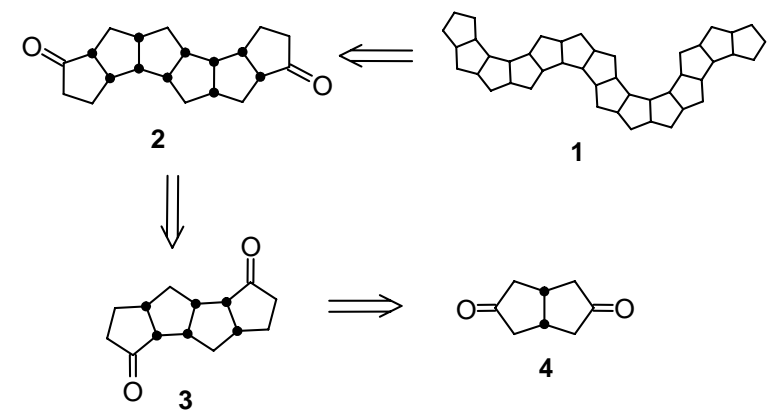

Figure 1. Retrosynthetic approach to helical polyquinane

Thus, the first stage of our approach to the unknown polypentanoid framework $\mathbf{2}$ involves the conversion of cis-bicyclo[3.3.0]octane dione unit $\mathbf{4}$ to tetraquinane $\mathbf{3}$ by bis-cyclopentane annulation procedure. Execution of cyclopentane annulation in a two-fold manner requires a method, which involves the fixing new carbonyl group at the $\beta$-position with respect to the original location during the simultaneous creation of two new cyclopentane rings.

The cyclopentane annulation strategy with appropriate stereochemistry at the ring junctions has been depicted in Scheme 1. The first step involves the reaction of the carbonyl compound 5 with allyl magnesium bromide ${ }^{7}$ followed by the hydroboration-oxidation sequence. The key step in this strategy is the generation of spiro-lactone 7 without the involvement of protective groups as compared to the literature methods. ${ }^{8-13}$ Treatment of the lactone with methanesulphonic acid$\mathrm{P}_{2} \mathrm{O}_{5}$ mixture generates the enone $\mathbf{8} .^{14,15}$ In the last step, the stereochemical control at the ring junctions may be achieved by catalytic cis-addition of the hydrogen to the olefin $\mathbf{8}$. The sequence of steps explained above was well implemented and the cornerstone of the methodology is the utilization of inexpensive reagents without the involvement of protective groups.

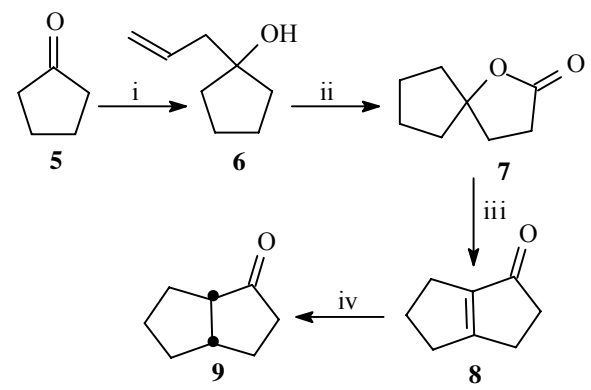

Scheme 1. (i) Allyl magnesium bromide; (ii) Hydroboration-Oxidation; (iii) Acid; (iv) Hydrohenation. 


\section{Results and Discussion}

The starting material cis-bicyclo[3.3.0]octane-3,7-dione 4, was prepared in multigram quantities using the Weiss-Cook reaction ${ }^{16}$ by $2: 1$ condensation of dimethyl-1,3-acetonedicarboxylate ${ }^{17}$ with glyoxal followed by hydrolysis and decarboxylation. The first stage towards the realization of the strategy involves the elaboration of the cis-bicyclo[3.3.0]octane-3,7-dione 4 to the tetracyclic dione $\mathbf{3}$ by the application of cyclopentane annulation strategy in a two-fold manner as exemplified in Scheme 2.

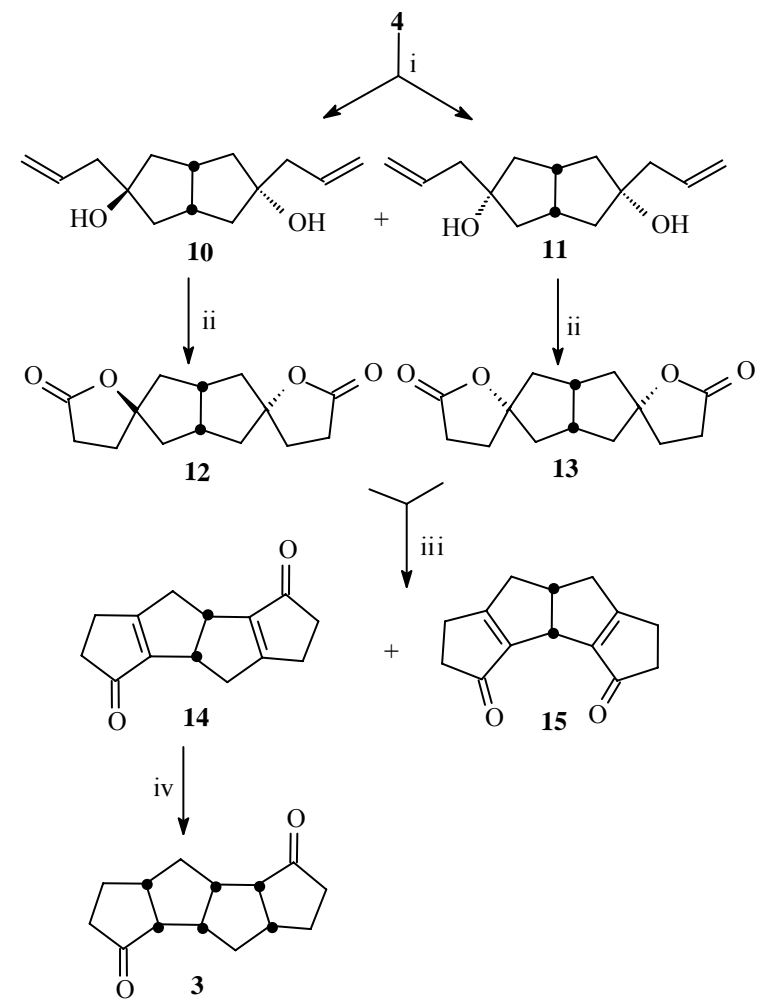

Scheme 2. (i) Allyl bromide, Mg-ether/THF; (ii) $\mathrm{NaBH}_{4}, \mathrm{BF}_{3}-\mathrm{Et}_{2} \mathrm{O}$, THF, Jones; (iii) Methanesulphonic acid, $\mathrm{P}_{2} \mathrm{O}_{5}$; (iv) $10 \% \mathrm{Pd} / \mathrm{C}$, EtOAc, $3 \mathrm{~atm}$.

Reaction of the dione $\mathbf{4}$ with excess of allylmagnesium bromide gave a mixture containing the homoallylic alcohols $\mathbf{1 0}$ and $\mathbf{1 1}$ as represented in Scheme 2. The unsymmetrical alcohol $\mathbf{1 0}$ and symmetrical alcohol 11 were isolated by silica-gel column chromatography $(9: 1,89 \%)$. The eleven-line ${ }^{13} \mathrm{C}$ NMR spectrum confirmed the unsymmetrical nature of the minor alcohol 10. The major alcohol 11 bears a $\mathrm{C}_{2}$-symmetry, which is in agreement with the six-line ${ }^{13} \mathrm{C}$ NMR spectrum. The homoallylic alcohols $\mathbf{1 0}$ and $\mathbf{1 1}$ were converted to the respective lactones by the hydroboration-oxidation sequence. In the subsequent experiments, the mixture of $\mathbf{1 0}$ and $\mathbf{1 1}$ were directly converted to the corresponding lactones 12 and 13 by one-pot operation (67\%). 
The stereochemistry of the dilactones $\mathbf{1 2}$ and $\mathbf{1 3}$ is of no consequence because the stereochemistry at spiro centers would be destroyed in the next step to generate the tetracyclic enones 14 and 15.

The number of steps in the strategy can be reduced by directly converting the dione 4 to the bis-lactones 12 or $\mathbf{1 3}$ in a single-step operation by the adaptation of the methods reported in the literature. ${ }^{18-20}$ However, our attempts to obtain the bis-lactone by one-step procedure as represented in Scheme 3 proved ineffective and the reductive coupling product $\mathbf{1 6}^{21}$ was obtained in low yield.

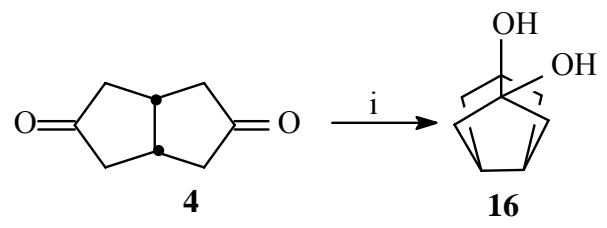

Scheme 3. (i) $\mathrm{CH}_{2}=\mathrm{CHCOOC}_{2} \mathrm{H}_{5}, \mathrm{Sml}_{2}$.

When the lactone mixture 12 and $\mathbf{1 3}$ was treated with methanesulphonic acid containing $8 \%$ $\mathrm{P}_{2} \mathrm{O}_{5}$, the tetracyclic enones $14(50 \%)$ and $15(16 \%)$ were formed. Hydrogenation of the tetracyclic system 14 in ethyl acetate containing $10 \% \mathrm{Pd} / \mathrm{C}$ at $3 \mathrm{~atm}$. pressure produced the saturated tetracyclic dione 3 (74\%). In principle, catalytic hydrogenation of the bis-enone 14 may furnish three possible isomers 3, 17 and $\mathbf{1 8}$ where the stereochemistry at the ring junctions is different. However, the required isomer 3 was obtained by purifying the catalyst ${ }^{14}$ prior to the reaction according to the procedure reported in the literature. The tetraquinanes containing trans ring junctions are not considered due to the strain involved in such systems.
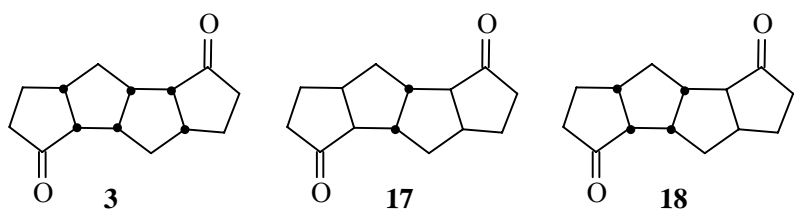

In an iterative approach, 3 was successfully elaborated to a novel hexacyclic system 2 as represented in Scheme 4. Reaction of dione 3 with excess allylmagnesium bromide gave a mixture containing the homoallylic alcohols 19 and 20, which was purified by silica gel column chromatography (79\%). The allylic alcohol 19 was converted to the lactone 21 via the hydroboration-oxidation sequence $(81 \%)$. The minor alcohol 20 was also converted to the lactone 22 by the hydroboration-oxidation sequence (67\%). The ${ }^{13} \mathrm{C}$ NMR of 19 and 21 exhibited ten signals suggesting the presence of $\mathrm{C}_{2}$-symmetry whereas compounds $\mathbf{2 0}$ and 22 exhibited twenty-lines characteristic of their unsymmetrical nature. The treatment of the bis-lactones 21 and 22 with $\mathrm{P}_{2} \mathrm{O}_{5}$ in methanesulphonic acid yielded not only the desired product 24, but also a novel transannular isomer 23 in equal proportions (combined yield, 26\%). The IR spectrum of 
the compound $23(13 \%)$ had two notable features, a normal carbonyl absorption at $1734 \mathrm{~cm}^{-1}$ and two sharp peaks at 1682 and $1612 \mathrm{~cm}^{-1}$ characteristic of an $\alpha, \beta$-unsaturated system. The mass spectral data of compound $23(\mathrm{~m} / \mathrm{z} 294)$ established its molecular formula as $\mathrm{C}_{20} \mathrm{H}_{22} \mathrm{O}_{2}$. Further, the presence of twenty carbon atoms was apparent in the proton-decoupled ${ }^{13} \mathrm{C} \mathrm{NMR}$ spectrum. Although the formation of $\mathbf{2 3}$ is very intriguing, we are unable to postulate any reasonable mechanism for the formation of heptacyclic $\alpha, \beta$-unsaturated enone. The structure of $\mathbf{2 3}$ was later established by X-ray diffraction analysis. ${ }^{23}$ Catalytic hydrogenation of 24 resulted in the formation of hexacyclic dione $2(70 \%)$ with the desired stereochemistry at the ten junctions and is represented in Scheme 4.

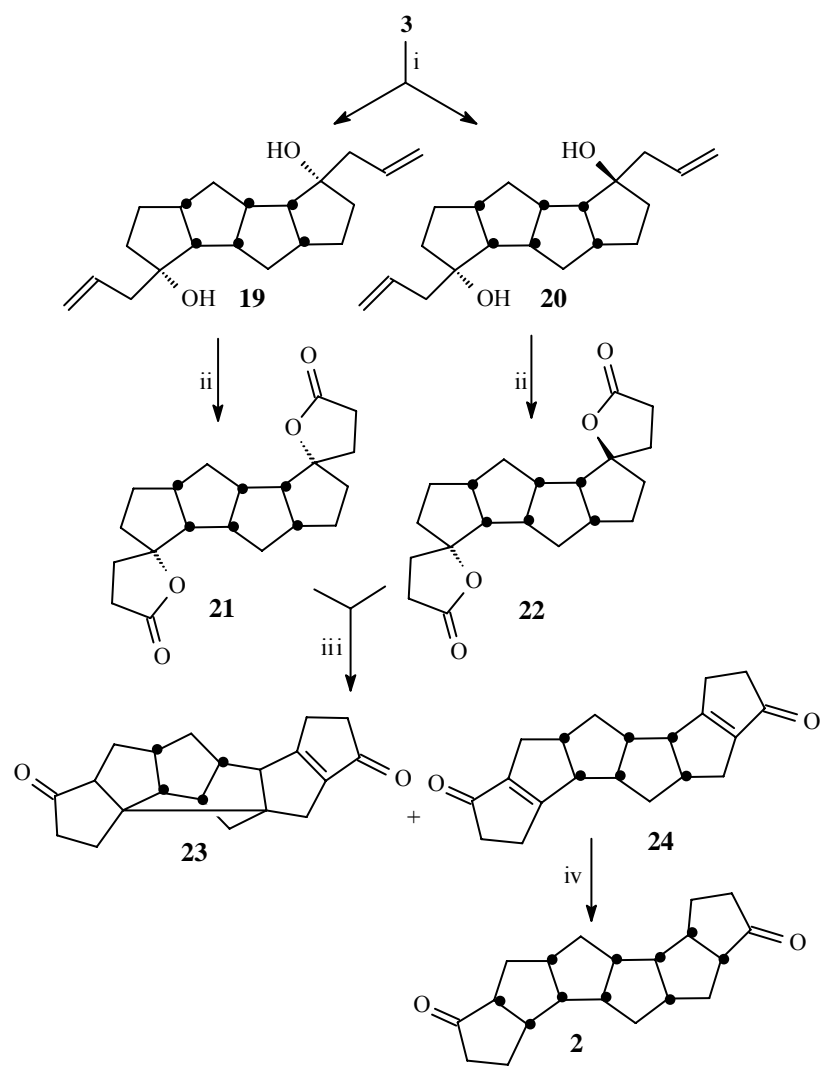

Scheme 4. (i) Allyl bromide, Mg-ether/THF; (ii) $\mathrm{NaBH}_{4}, \mathrm{BF}_{3}-\mathrm{Et}_{2} \mathrm{O}$, THF, Jones; (iii) Methanesulphonic acid, $\mathrm{P}_{2} \mathrm{O}_{5}$; (iv) $10 \% \mathrm{Pd} / \mathrm{C}$, EtOAc, 3 atm.

\section{Conclusions}

In our efforts directed towards the synthesis of complex polyquinane frameworks like 1, the bicyclic dione 4 was elaborated to $\mathrm{C}_{2}$-symmetrical $\mathrm{C}_{20}$-hexaquinane 2 by the application of iterative cyclopentane annulation strategy. The hexaquinane 2 was prepared in a 8 step sequence with a reasonable yield. The accessibility of the hexaquinane derivatives such as 2 in good 
quantities would open up an alternate synthetic route to $\mathbf{1}$ by application of suitable cyclopentane annulation strategy. Further, a simple and straightforward methodology developed here may find application in the synthesis of various natural products bearing the cyclopentanoid frameworks.

\section{Experimental Section}

General Procedures. Analytical thin layer chromatography (TLC) were performed on (10 $\times$ $5 \mathrm{~cm}$ ) glass plate coated with Acme's silica gel G or GF 254 (containing 13\% calcium sulfate as a binder). Visualization of the spot on TLC plate was achieved either by exposure to iodine vapor, or UV light. Flash chromatography was performed using Acme's silica gel (100-200 mesh) and the column was usually eluted with ethyl acetate and petroleum ether mixture. Melting points are uncorrected. Infrared spectra (FT-IR) were recorded as $\mathrm{KBr}$ pellets unless otherwise mentioned. UV spectra were taken in $\mathrm{CH}_{3} \mathrm{OH}$ solvent. Dry THF and diethyl ether were obtained by distillation over sodium-benzophenone ketyl. Allyl bromide was purified according to the standard procedure. Boron trifluoride etherate was distilled over $\mathrm{CaH}_{2}$. Yields reported are isolated yields of the materials. Allyl bromide was purchased from E-Merck India, boron trifluoride etherate and methanesulphonic acid from Lancaster Synthesis Ltd., (U.K.). ${ }^{1} \mathrm{H}$ NMR spectra were recorded on EM-300 spectrometer. $300 \mathrm{MHz}{ }^{1} \mathrm{H}$ and $75.4 \mathrm{MHz}{ }^{13} \mathrm{C}$ NMR spectra were recorded on Bruker spectrometer.

Compound (10) and (11). To activated magnesium turnings (15 g, $0.61 \mathrm{~mol})$, allyl bromide (20 $\mathrm{mL}, 0.23 \mathrm{~mol})$ in dry ether $(80 \mathrm{~mL})$ was added at $0{ }^{\circ} \mathrm{C}$ and the mixture was stirred for $1-2 \mathrm{~h}$ at RT. The dione $4(8 \mathrm{~g}, 0.05 \mathrm{~mol})$ in dry THF $(30 \mathrm{~mL})$ was then added to the Grignard reagent at $0{ }^{\circ} \mathrm{C}$ and stirred for another $1-2 \mathrm{~h}$ at $\mathrm{rt}$. The reaction mixture was poured into the saturated ammonium chloride solution $(100 \mathrm{~mL})$ and the THF was removed at reduced pressure. The reaction mixture was extracted with ethyl acetate $(250 \mathrm{~mL})$ and the organic layer was washed with water, brine and dried. The solvent was evaporated, and the crude product was purified by silica gel column chromatography.

Elution of the column with $90 \%$ pet ether-ethyl acetate mixture furnished the minor alcohol 10 $(1.14 \mathrm{~g}) . \mathrm{Mp}: 104-106^{\circ} \mathrm{C} . R_{f}: 0.62$ (75\% pet ether-ethyl acetate). IR (KBr): v 3340, 3075, 2953, 2863, 1636, 1426, $916 \mathrm{~cm}^{-1} .{ }^{1} \mathrm{H} \mathrm{NMR}\left(300 \mathrm{MHz}, \mathrm{CDCl}_{3}\right): \delta$ 5.78-5.94 (m, 2H), 5.08-5.18 (m, 4H), 2.7-2.8 (m, 2H), 2.28-2.36 (m, 5H), 1.84-1.92 (m, 5H), 1.63-1.7 (m, 2H), 1.5-1.54 (m, 2H). ${ }^{13} \mathrm{C} \mathrm{NMR}\left(75 \mathrm{MHz}, \mathrm{CDCl}_{3}\right.$ ): $\delta$ 135.3, 134.9, 119.7, 119.1, 84.8, 84.6, 47.5, 46.4, 46.0, 45.8, 41.9. MS: $m / z 204$ [M $\left.{ }^{+}-\mathrm{H}_{2} \mathrm{O}\right]$. Anal.: for $\mathrm{C}_{14} \mathrm{H}_{22} \mathrm{O}_{2}$ Calcd: $75.63(\mathrm{C}), 9.97(\mathrm{H})$; Found: $75.55(\mathrm{C}), 10.17$ (H).

Further elution of the column with $85 \%$ pet ether-ethyl acetate mixture gave the major alcohol $11(10.31 \mathrm{~g})$. The major alcohol 11 and the minor alcohol 10 were obtained in the ratio 9:1 (combined yield 89\%). Mp: $82-84{ }^{\circ} \mathrm{C} . R_{f}: 0.30$ (75\% pet ether-ethyl acetate). IR (KBr): $v$ 3180, 3077, 2935, 2852, 1639, 1463, $903 \mathrm{~cm}^{-1} .{ }^{1} \mathrm{H}$ NMR (300 MHz, $\left.\mathrm{CDCl}_{3}\right): \delta$ 5.60-5.80 (m, 
2H), 5.08-5.15 (m, 4H), 3.0 (bs, 2H), 2.60-2.69 (m, 2H), 2.26-2.29 (m, 4H), 1.92-2.0 (m, 4H), 1.73-1.79 (m, 4H). $\left.{ }^{13} \mathrm{C} \mathrm{NMR} \mathrm{(75} \mathrm{MHz,} \mathrm{CDCl}_{3}\right): \delta 135.4,118.5,84.2,47.2,46.4,42.6 . \mathrm{MS}: \mathrm{m} / z$ 204 [ $\mathrm{M}^{+}-\mathrm{H}_{2} \mathrm{O}$ ]. Anal.: for $\mathrm{C}_{14} \mathrm{H}_{22} \mathrm{O}_{2}$ Calcd: $75.63(\mathrm{C}), 9.97(\mathrm{H})$; Found: $75.44(\mathrm{C}), 10.11(\mathrm{H})$.

Compounds 19 and 20. To activated magnesium turnings (0.7 g, $28.8 \mathrm{mmol})$, allyl bromide $(3 \mathrm{~mL}, 34.66 \mathrm{mmol})$ in dry ether $(30 \mathrm{~mL})$ was added at $0{ }^{\circ} \mathrm{C}$ and the mixture was stirred for $1-2 \mathrm{~h}$ at RT. The dione 3 (148 $\mathrm{mg}, 0.67 \mathrm{mmol})$ in dry THF $(30 \mathrm{~mL})$ was then added to the Grignard reagent at $0{ }^{\circ} \mathrm{C}$ and stirred for another $1-2 \mathrm{~h}$ at $\mathrm{rt}$. The reaction mixture was poured into the saturated ammonium chloride solution $(100 \mathrm{~mL})$ and the THF was removed at reduced pressure. The reaction mixture was extracted with ethyl acetate $(250 \mathrm{~mL})$ and the organic layer was washed with water, brine and dried. The solvent was evaporated, and the crude product was purified by silica gel column chromatography.

Elution of the column with $95 \%$ pet ether-ethyl acetate mixture furnished the major allylic alcohol 19 (115 mg). Mp: $134-136{ }^{\circ} \mathrm{C} . R_{f}: 0.67$ (80\% pet ether-ethyl acetate). IR (KBr): $v 3452$, 3073, 2933, 1639, 1466, 1142, $1025 \mathrm{~cm}^{-1} .{ }^{1} \mathrm{H}$ NMR (300 MHz, $\left.\mathrm{CDCl}_{3}\right): \delta 5.84-5.98(\mathrm{~m}, 2 \mathrm{H})$, 5.09-5.18 (m, 4H), 2.04-2.59 (m, 10H), 1.43-1.82 (m, 14H). ${ }^{13} \mathrm{C}$ NMR $\left(75 \mathrm{MHz}, \mathrm{CDCl}_{3}+\mathrm{CCl}_{4}\right)$ : $\delta$ 134.5, 118.7, 81.9, 52.4, 50.8, 46.3, 45.5, 40.1, 36.6, 29.2. MS: $m / z 284\left[\mathrm{M}^{+}-\mathrm{H}_{2} \mathrm{O}\right]$. Anal. for $\mathrm{C}_{20} \mathrm{H}_{30} \mathrm{O}_{2}$ Calcd: $79.42(\mathrm{C}), 9.99(\mathrm{H})$; Found: $79.84(\mathrm{C}), 10.02(\mathrm{H})$.

Further elution of the column with $90 \%$ pet ether-ethyl acetate mixture gave the minor alcohol 20 (46 mg). The stereoisomers 19 and 20 were obtained in the ratio 3:1 (combined yield 78\%). Mp: $99-101{ }^{\circ} \mathrm{C} . R_{f}: 0.45$ (80\% pet ether-ethyl acetate). IR (KBr): v3339, 3073, 2942, 2864, 1637 , 1457, 1139, 1042, $909 \mathrm{~cm}^{-1} .{ }^{1} \mathrm{H}$ NMR $\left(300 \mathrm{MHz}, \mathrm{CDCl}_{3}\right): \delta 5.74-5.85(\mathrm{~m}, 2 \mathrm{H}), 5.0-5.09(\mathrm{~m}, 4 \mathrm{H})$, 2.14-2.64 (m, 10H), 0.98-1.93 (m, 14H). $\left.{ }^{13} \mathrm{C} \mathrm{NMR} \mathrm{(75} \mathrm{MHz,} \mathrm{CDCl}_{3}+\mathrm{CCl}_{4}\right): \delta 134.46,134.41$, 118.8, 118.6, 81.8, 81.0, 55.2, 54.6, 49.4, 46.8, 46.7, 46.4, 44.9, 43.3, 40.7, 40.6, 39.9, 34.5, 31.1, 29.6. MS: $m / z 284\left[\mathrm{M}^{+}-\mathrm{H}_{2} \mathrm{O}\right]$. Anal. for $\mathrm{C}_{20} \mathrm{H}_{30} \mathrm{O}_{2}$ Calcd: $79.42(\mathrm{C}), 9.99(\mathrm{H})$, Found: 79.52 (C), $10.21(\mathrm{H})$.

Compounds 12. To a stirred solution of the diol $10(60 \mathrm{mg}, 0.27 \mathrm{mmol})$ and $\mathrm{NaBH}_{4}(65 \mathrm{mg}$, $1.71 \mathrm{mmol})$ in dry THF $(15 \mathrm{~mL})$, freshly distilled $\mathrm{BF}_{3} . \mathrm{OEt}_{2}(0.6 \mathrm{~mL}, 4.8 \mathrm{mmol})$ in dry THF $(3 \mathrm{~mL})$ was added at $0{ }^{\circ} \mathrm{C}$ over a period of $30 \mathrm{~min}$. The reaction was stirred at $\mathrm{RT}$ for $1-2 \mathrm{~h}$ and cooled to $0{ }^{\circ} \mathrm{C}$. Freshly prepared Jones reagent $(4 \mathrm{~mL})$ was added dropwise. The solution was stirred at RT for 2-3 $\mathrm{h}$ and the THF was removed at reduced pressure. The reaction mixture was extracted with ethyl acetate $(150 \mathrm{~mL})$ and the organic layer was washed with water, brine and dried. Removal of the solvent gave the crude lactone, which was charged on a silica gel column. Elution of the column with 50\% hexane-ethyl acetate furnished the pure lactone 12 (42 $\mathrm{mg}$, 63\%). Mp: $138-139{ }^{\circ}$ C. $R_{f}: 0.44$ (ethyl acetate). IR (KBr): v 2939, 2871, 1761, 1459, 1197, 1171, 1132, $1075 \mathrm{~cm}^{-1} .{ }^{1} \mathrm{H}$ NMR (300 MHz, $\left.\mathrm{CDCl}_{3}\right): \delta 2.94$ (bs, 2H), 2.50-2.58 (m, 4H), 2.15-2.25 (m, $6 \mathrm{H}), 1.79-1.92(\mathrm{~m}, 6 \mathrm{H}) .{ }^{13} \mathrm{C} \mathrm{NMR}\left(75 \mathrm{MHz}, \mathrm{CDCl}_{3}+\mathrm{CCl}_{4}\right): \delta 176.2,175.9,96.7,96.6,45.0$, 43.9, 41.3, 31.9, 29.9, 29.6, 29.0. MS: $m / z 250\left[\mathrm{M}^{+}\right]$. Anal. for $\mathrm{C}_{14} \mathrm{H}_{18} \mathrm{O}_{4}$ Calcd: 67.18 (C), 7.25 (H); Found: $67.05(\mathrm{C}), 7.54(\mathrm{H})$.

Compounds 13. To a stirred solution of the diol 11 (2 g, $9 \mathrm{mmol})$ and $\mathrm{NaBH}_{4}(1.25 \mathrm{~g}, 33 \mathrm{mmol})$ in dry THF $(50 \mathrm{~mL})$, freshly distilled $\mathrm{BF}_{3} . \mathrm{OEt}_{2}(8 \mathrm{~mL}, 65 \mathrm{mmol})$ in dry THF $(3 \mathrm{~mL})$ was added 
at $0{ }^{\circ} \mathrm{C}$ over a period of $30 \mathrm{~min}$. The reaction was stirred at RT for $1-2 \mathrm{~h}$ and cooled to $0{ }^{\circ} \mathrm{C}$. Freshly prepared Jones reagent $(10 \mathrm{~mL})$ was added dropwise. The solution was stirred at RT for 2-3 $\mathrm{h}$ and the THF was removed at reduced pressure. The reaction mixture was extracted with ethyl acetate $(150 \mathrm{~mL})$ and the organic layer was washed with water, brine and dried. Removal of the solvent gave the crude lactone, which was charged on a silica gel column. Elution of the column (silica gel) with 40\% pet ether-ethyl acetate furnished the pure lactone 13 (1.4 g, 62\%). Mp: $170-171{ }^{\circ} \mathrm{C} . R_{f}: 0.26$ (40\% pet ether-ethyl acetate). IR (KBr): v 2935, 2881, 1760, 1463, $1184,1104,1064 \mathrm{~cm}^{-1} .{ }^{1} \mathrm{H}$ NMR $\left(300 \mathrm{MHz}, \mathrm{CDCl}_{3}\right): \delta 1.89-2.05(\mathrm{~m}, 6 \mathrm{H}), 2.09-2.18(\mathrm{~m}, 6 \mathrm{H})$, 2.5-2.72 (m, 6H). $\left.{ }^{13} \mathrm{C} \mathrm{NMR} \mathrm{(75} \mathrm{MHz,} \mathrm{CDCl}_{3}\right): \delta$ 177.0, 94.7, 44.1, 39.3, 33.1, 29.6. MS: $m / z 250$ $\left[\mathrm{M}^{+}\right]$. Anal. for $\mathrm{C}_{14} \mathrm{H}_{18} \mathrm{O}_{4}$ Calcd. $67.18(\mathrm{C}) 7.25(\mathrm{H})$; Found: $67.31(\mathrm{C}), 7.07(\mathrm{H}) \%$.

Compounds 21. To a stirred solution of the diol $19(20 \mathrm{mg}, 0.06 \mathrm{mmol})$ and $\mathrm{NaBH}_{4}(30 \mathrm{mg}$, $0.79 \mathrm{mmol})$ in dry THF $(20 \mathrm{~mL})$, freshly distilled $\mathrm{BF}_{3} . \mathrm{OEt}_{2}(2.4 \mathrm{mmol})$ in dry THF $(5 \mathrm{~mL})$ was added at $0{ }^{\circ} \mathrm{C}$ over a period of $30 \mathrm{~min}$. The reaction was stirred at RT for $1-2 \mathrm{~h}$ and cooled to $0{ }^{\circ} \mathrm{C}$. Freshly prepared Jones reagent $(5 \mathrm{~mL})$ was added dropwise. The solution was stirred at RT for $2-3 \mathrm{~h}$ and the THF was removed at reduced pressure. The reaction mixture was extracted with ethyl acetate $(150 \mathrm{~mL})$ and the organic layer was washed with water, brine and dried. Removal of the solvent gave the crude lactone, which was charged on a silica gel column. Elution of the column with 40\% pet ether-ethyl acetate furnished the pure lactone 21 (17 mg, 81\%). Mp: 212$214{ }^{\circ} \mathrm{C} . R_{f}: 0.55$ (ethyl acetate). IR (KBr): $v 2962,2926,1752,1470,1145,1064,1025,916 \mathrm{~cm}^{-1}$. ${ }^{1} \mathrm{H}$ NMR $\left(300 \mathrm{MHz}, \mathrm{CDCl}_{3}\right): \delta 2.37-2.70(\mathrm{~m}, 10 \mathrm{H}), 2.05-2.24(\mathrm{~m}, 8 \mathrm{H}), 1.35-1.82(\mathrm{~m}, 8 \mathrm{H}) .{ }^{13} \mathrm{C}$ NMR (75 MHz, $\left.\mathrm{CDCl}_{3}\right): \delta 177.2,94.2,52.3,51.3,44.0,38.2,36.1,36.0,28.7,28.5$. MS: $\mathrm{m} / z$ $330\left[\mathrm{M}^{+}\right]$. HRMS (EI): $m / z$ for $\mathrm{C}_{20} \mathrm{H}_{26} \mathrm{O}_{4}\left[\mathrm{M}^{+}\right]$: Calcd 330.1831; Found: 330.1829 .

Compounds 22. To a stirred solution of the diol $20(93 \mathrm{mg}, 0.31 \mathrm{mmol})$ and $\mathrm{NaBH}_{4}(130 \mathrm{mg}$, $3.43 \mathrm{mmol})$ in dry THF $(25 \mathrm{~mL})$, freshly distilled $\mathrm{BF}_{3} . \mathrm{OEt}_{2}(1 \mathrm{~mL}, 8.1 \mathrm{mmol})$ in dry THF $(10 \mathrm{~mL})$ was added at $0{ }^{\circ} \mathrm{C}$ over a period of $30 \mathrm{~min}$. The reaction was stirred at RT for $1-2 \mathrm{~h}$ and cooled to $0{ }^{\circ} \mathrm{C}$. Freshly prepared Jones reagent $(5 \mathrm{~mL})$ was added dropwise. The solution was stirred at RT for 2-3 $\mathrm{h}$ and the THF was removed at reduced pressure. The reaction mixture was extracted with ethyl acetate $(150 \mathrm{~mL})$ and the organic layer was washed with water, brine and dried. Removal of the solvent gave the crude lactone, which was charged on a silica gel column. The reaction was done according to the general procedure. Elution of the column with $70 \%$ pet ether-ethyl acetate furnished the pure lactone $22(78 \mathrm{mg}, 77 \%)$. Mp: $104-106{ }^{\circ} \mathrm{C} . R_{f}: 0.4(50 \%$ pet ether-ethyl acetate). IR (KBr): $v 2939,2874,1756,1462,1165,1059 \mathrm{~cm}^{-1} .{ }^{1} \mathrm{H}$ NMR (300 $\left.\mathrm{MHz}, \mathrm{CDCl}_{3}\right): \delta 2.32-2.71(\mathrm{~m}, 10 \mathrm{H}), 1.70-2.13(\mathrm{~m}, 12 \mathrm{H}), 1.09-1.47(\mathrm{~m}, 4 \mathrm{H}) .{ }^{13} \mathrm{C}$ NMR $(75$ $\left.\mathrm{MHz}, \mathrm{CDCl}_{3}+\mathrm{CCl}_{4}\right): \delta 176.1,175.9,94.6,93.5,56.2,54.5,49.7,46.2,44.0,43.9,39.7,39.2$, 35.3, 34.6, 32.9, 30.8, 29.3, 29.2, 29.0, 28.6. MS: $m / z 330\left[\mathrm{M}^{+}\right]$. HRMS (EI): $m / z$ for $\mathrm{C}_{20} \mathrm{H}_{26} \mathrm{O}_{4}$ $\left[\mathrm{M}^{+}\right]$: Calcd 330.1831; Found: 330.1826 .

Compounds 14 and 15. The bis-lactone mixture 12 and $13(1.03 \mathrm{~g}, 4.11 \mathrm{mmol})$ was dissolved in methanesulphonic acid $(20 \mathrm{~mL})$ and approximately $30 \mathrm{mg}$ of $\mathrm{P}_{2} \mathrm{O}_{5}$ was added. The reaction mixture was heated at $50-55{ }^{\circ} \mathrm{C}$ for $6 \mathrm{~h}$, cooled to $0{ }^{\circ} \mathrm{C}$ and diluted with water $(40 \mathrm{~mL})$. The reaction mixture was extracted with chloroform $(150 \mathrm{~mL})$ and the organic layer was washed with 
saturated sodium bicarbonate solution $(75 \mathrm{~mL})$, brine and dried. Evaporation of the solvent at reduced pressure gave the crude product as a mixture of isomers (TLC) which was purified by a silica gel column. Careful elution of the column with $70 \%$ pet ether-ethyl acetate mixture gave the major product $14(0.438 \mathrm{~g})$. Mp: $199-201{ }^{\circ} \mathrm{C} . R_{f}: 0.44$ (ethyl acetate). IR (KBr): $v 2924,2848$, 1693, 1629, 1434, 1041, $924 \mathrm{~cm}^{-1}$. UV $\left(\mathrm{CH}_{3} \mathrm{OH}\right): \lambda_{\max } \mathrm{nm}\left(\varepsilon \mathrm{lit} \mathrm{mol}^{-1} \mathrm{~cm}^{-1}\right) 232(10555) .{ }^{1} \mathrm{H} \mathrm{NMR}$ $\left(300 \mathrm{MHz}, \mathrm{CDCl}_{3}\right): \delta 3.9-4.13(\mathrm{~m}, 2 \mathrm{H}), 2.6-2.85(\mathrm{~m}, 6 \mathrm{H}), 2.44-2.51(\mathrm{~m}, 6 \mathrm{H}) .{ }^{13} \mathrm{C}$ NMR $(75$ $\left.\mathrm{MHz}, \mathrm{CDCl}_{3}\right): \delta$ 203.6, 185.3, 149.0, 47.0, 41.0, 35.1, 25.4. MS: $m / z 214\left[\mathrm{M}^{+}\right]$. Anal. for $\mathrm{C}_{14} \mathrm{H}_{14} \mathrm{O}_{2}$ Calcd: $78.47(\mathrm{C}), 6.58(\mathrm{H})$; Found: $77.53(\mathrm{C}), 6.39(\mathrm{H})$.

Further elution of the column with $60 \%$ pet ether-ethyl acetate mixture gave the minor product $15(0.1436 \mathrm{~g})$. The major and the minor enones were obtained in the ratio 3:1 (combined yield: 66\%). Mp: $168-171{ }^{\circ} \mathrm{C} . R_{f}: 0.21$ (ethyl acetate). IR (KBr): v 2929, 2839, 1694, 1631, 1434, 1053, $973 \mathrm{~cm}^{-1}$. UV $\left(\mathrm{CH}_{3} \mathrm{OH}\right): \lambda_{\max } \mathrm{nm}\left(\varepsilon\right.$ lit $\left.\mathrm{mol}^{-1} \mathrm{~cm}^{-1}\right) 230(5645) .{ }^{1} \mathrm{H}$ NMR $\left(300 \mathrm{MHz}, \mathrm{CDCl}_{3}\right): \delta$ 3.93-4.05 (m, 1H), 3.8-3.85 (m, 1H), 2.87-2.9 (m, 2H), 2.69-2.72 (m, 4H), 2.46-2.49 (m, 6H). ${ }^{13} \mathrm{C} \mathrm{NMR}\left(75 \mathrm{MHz}, \mathrm{CDCl}_{3}\right): \delta$ 201.7, 185.3, 148.1, 51.9, 43.3, 40.7, 39.7, 25.4. MS: $m / z 214$ $\left[\mathrm{M}^{+}\right]$. Anal. for $\mathrm{C}_{14} \mathrm{H}_{14} \mathrm{O}_{2}$ Calcd: $78.47(\mathrm{C}), 6.58(\mathrm{H})$; Found: $78.75(\mathrm{C}), \mathrm{H}, 6.81 \%$.

Compounds 23 and 24. The bis-lactone mixture 21 and $22(215 \mathrm{mg}, 0.65 \mathrm{mmol})$ was dissolved in methanesulphonic acid $(10 \mathrm{~mL})$ and approximately $15 \mathrm{mg}$ of $\mathrm{P}_{2} \mathrm{O}_{5}$ was added. The reaction mixture was heated at $50-55{ }^{\circ} \mathrm{C}$ for $6 \mathrm{~h}$, cooled to $0{ }^{\circ} \mathrm{C}$ and diluted with water $(40 \mathrm{~mL})$. The reaction mixture was extracted with chloroform $(150 \mathrm{~mL})$ and the organic layer was washed with saturated sodium bicarbonate solution $(75 \mathrm{~mL})$, brine and dried. Evaporation of the solvent at reduced pressure gave the crude product as a mixture of isomers (TLC) which was purified by a silica gel column. Careful elution of the column with $40 \%$ pet ether-ethyl acetate mixture gave the transannular product $23(25 \mathrm{mg})$. Mp: $124-126{ }^{\circ} \mathrm{C} . R_{f}: 0.78$ (30\% pet ether-ethyl acetate). IR $(\mathrm{KBr}): v 2936,2868,1734,1682,1612,1438,1024 \mathrm{~cm}^{-1}$. UV $\left(\mathrm{CH}_{3} \mathrm{OH}\right): \lambda_{\max } \mathrm{nm}\left(\varepsilon \mathrm{lit} \mathrm{mol}^{-1} \mathrm{~cm}^{-1}\right)$ 244 (10,688). ${ }^{1} \mathrm{H}$ NMR (300 MHz, $\left.\mathrm{CDCl}_{3}\right): \delta 2.37-2.78(\mathrm{~m}, 12 \mathrm{H}), 1.48-2.23(\mathrm{~m}, 10 \mathrm{H}) .{ }^{13} \mathrm{C}$ NMR (75 MHz, $\left.\mathrm{CDCl}_{3}\right): \delta 222.8,204.5,189.0,145.9,65.6,63.0,61.0,57.4,52.7,50.4,43.7$, 43.5, 43.4, 42.8, 42.7, 39.8, 36.9, 28.9, 25.6, 24.7. Mass: $m / z 294\left[\mathrm{M}^{+}\right]$. HRMS (EI): $m / z$ for $\mathrm{C}_{20} \mathrm{H}_{22} \mathrm{O}_{2}\left[\mathrm{M}^{+}\right]$: Calcd: 294.1619. Found: 294.1608.

Further elution of the column with $25 \%$ pet ether-ethyl acetate mixture gave the required hexacyclic enone 24 (25 mg). The compounds 23 and 24 were obtained in equal ratio (combined yield: 26\%). Mp: $156{ }^{\circ} \mathrm{C} . R_{f}: 0.68$ (pet ether-ethyl acetate). IR (KBr): v 2933, 2850, 1679, 1623,1439, $1022 \mathrm{~cm}^{-1}$. UV $\left(\mathrm{CH}_{3} \mathrm{OH}\right): \lambda_{\max } \mathrm{nm}\left(\varepsilon\right.$ lit $\left.\mathrm{mol}^{-1} \mathrm{~cm}^{-1}\right) 242(2,792), 209(3,761) .{ }^{1} \mathrm{H}$ NMR (300 MHz, $\left.\mathrm{CDCl}_{3}\right): \delta 3.27-3.38(\mathrm{~m}, 2 \mathrm{H}), 2.99-3.01(\mathrm{~m}, 2 \mathrm{H}), 2.33-2.74(\mathrm{~m}, 10 \mathrm{H}), 2.04-2.11$ (m, 2H), 1.64-1.92 (m, 6H). ${ }^{13} \mathrm{C}$ NMR (75 MHz, $\left.\mathrm{CDCl}_{3}\right): \delta$ 204.6, 187.9, 146.6, 55.0, 47.7, 47.5, 40.8, 40.6, 31.7, 24.3. MS: $m / z 294\left[\mathrm{M}^{+}\right]$. HRMS (EI): $m / z$ for $\mathrm{C}_{20} \mathrm{H}_{22} \mathrm{O}_{2}\left[\mathrm{M}^{+}\right]$: Calcd: 294.1619. Found: 294.1616.

Compound (2). The enone $24(38 \mathrm{mg}, 0.13 \mathrm{mmol})$ in ethyl acetate $(20 \mathrm{~mL})$ was hydrogenated with $10 \% \mathrm{Pd} / \mathrm{C}(10 \mathrm{mg})$ at $3 \mathrm{~atm}$ pressure for $3 \mathrm{~h}$. The reaction mixture was filtered and the solvent was removed at reduced pressure. The dione was further purified using a silica gel 
column. Elution of the column with $90 \%$ pet ether-ethyl acetate mixture furnished the required saturated hexacyclic diketone 2 (27 mg, 70\%). Mp: $111-113{ }^{\circ} \mathrm{C} . R_{f}: 0.61$ (50\% pet ether-ethyl acetate). IR (KBr): $v$ 2924, 2861, 1738, 1466, 1158, $985 \mathrm{~cm}^{-1} .{ }^{1} \mathrm{H}$ NMR $\left(300 \mathrm{MHz}, \mathrm{CDCl}_{3}\right): \delta$ 2.21-2.89 (m, 14H), 1.94-2.15 (m, 4H), 1.25-1.76 (m, 8H). $\left.{ }^{13} \mathrm{C} \mathrm{NMR} \mathrm{(75} \mathrm{MHz,} \mathrm{CDCl}_{3}\right): \delta 221.3$, 55.1, 53.2, 47.4, 46.7, 45.7, 39.2, 38.3, 33.7, 23.5. MS: $m / z 298\left[\mathrm{M}^{+}\right]$. HRMS (EI): $m / z$ for $\mathrm{C}_{20} \mathrm{H}_{26} \mathrm{O}_{2}\left[\mathrm{M}^{+}\right]$: Calcd: 298.1932. Found: 298.1929.

Compound (3). The enone $14(161 \mathrm{mg}, 0.73 \mathrm{mmol})$ in ethyl acetate $(30 \mathrm{~mL})$ was hydrogenated with $10 \% \mathrm{Pd} / \mathrm{C}(15 \mathrm{mg})$ at $3 \mathrm{~atm}$ pressure for $3-4 \mathrm{~h}$. The reaction mixture was filtered and the solvent was removed at reduced pressure. The dione was further purified using a silica gel column. Elution of the column with $90 \%$ pet ether-ethyl acetate mixture furnished the required saturated diketone 3 (122 mg, 74\%). Mp: $95-97{ }^{\circ} \mathrm{C}$ (Lit. mp: $100-101{ }^{\circ} \mathrm{C}{ }^{22}$ ). $R_{f}: 0.64$ (80\% pet ether-ethyl acetate). IR (KBr): $v 2948,1730,1463,1034,926 \mathrm{~cm}^{-1} .{ }^{1} \mathrm{H}$ NMR $\left(300 \mathrm{MHz}, \mathrm{CDCl}_{3}\right)$ : $\delta$ 2.60-2.95 (m, 6H), 2.20-2.36 (m, 4H), 1.77-2.19 (m, 6H), 0.85-1.0 (m, 2H). ${ }^{13} \mathrm{C}$ NMR $(75$ $\left.\mathrm{MHz}, \mathrm{CDCl}_{3}+\mathrm{CCl}_{4}\right): \delta 220.2,52.7,49.5,44.2,37.5,34.7,24.0 . \mathrm{MS}: m / z 218\left[\mathrm{M}^{+}\right]$.

\section{Acknowledgements}

We thank CSIR, New Delhi for the financial support. The authors thank Prof. A. Srikrishna and the Department of Organic Chemistry, IISc, Bangalore-560012, India for providing the NMR spectral data. RS thanks CSIR for the award of fellowship.

\section{References}

1. (a) Mehta, G. J. Sci. Ind. Res. (India) 1978, 37, 256. (b) Eaton, P. E. Tetrahedron 1979, 35, 2189.

2. Paquette, L. A. Chem. Rev. 1989, 89, 1051.

3. Prinzbach, H.; Weber, K. Angew. Chem., Int. Ed. 1994, 33, 2239.

4. (a) Mehta, G.; Srikrishna, A. Chem. Rev. 1997, 97, 671. (b) Singh, V.; Thomas, B. Tetrahedron 1998, 54, 3647.

5. Kotha, S.; Sivakumar, R.; Damodharan, L.; Pattabhi, V. Tetrahedron Lett. 2002, 43, 4523.

6. (a) Magnuson, S. R. Tetrahedron 1995, 51, 2167. (b) Camps, P.; Lukach, A. E.; Vázquez, S. Tetrahedron 2001, 57, 2419.

7. Hao, N. C.; Mavrov, M. V.; Chrelashvili, Z. G.; Serebryakov, E. P. Izv. Akad. Nauk SSSR, 1988, 1042 (Engl. Translation).

8. Kano, S.; Shibuya, S.; Ebata, T. Heterocycles 1980, 14, 661.

9. Schlecht, M. F.; Kim, H-J. Tetrahedron Lett. 1985, 26, 127.

10. Periaswamy, M.; Narayana, C.; Anitha, N. Ind. J. Chem. 1986, 25 B, 844. 
11. Rathore, R.; Vankar, P. S.; Chandrasekaran, S. Tetrahedron Lett. 1986, 27, 4079.

12. Mandal, A. K.; Mahajan, S. W. Synthesis, 1991, 311.

13. Dhillon, R. S.; Nayyar, K.; Singh, J. Tetrahedron Lett. 1992, 33, 6015.

14. Eaton, P. E.; Muller, R. H.; Carlson, G. R.; Cullison, D. A.; Cooper, G. F.; Chou, T. C.; Krebs, E. P. J. Am. Chem. Soc. 1977, 99, 2751.

15. Vankar, P. S.; Chandrasekaran, S. Bull. Chem. Soc. Jpn. 1989, 62, 1388.

16. Bertz, S. H.; Cook, J. M.; Gawish, A.; Weiss, U. Org. Syn. Coll. Vol. VII, 1990, p 50.

17. Kotha, S.; Joseph, A.; Sivakumar, R.; Manivannan, E. Ind. J. Chem. 1998, 37B, 397.

18. Ranu, B. C.; Majee, A.; Das, A. R. Tetrahedron Lett. 1995, 36, 4885.

19. Fukuzawa, S. I.; Fujinami, T.; Sakai, S. J. Chem. Soc., Chem. Comm. 1986, 475. Otsubo, K.; Kawamura, K.; Inanaga, J.; Yamaguchi, M. Chem. Lett. 1987, 1487.

20. Corey, E. J.; Zheng, G. Z. Tetrahedron Lett. 1997, 38, 2045.

21. McKervey, M. A.; Vibuljan, P.; Ferguson, G.; Siew, P. Y. J. Chem. Soc., Chem. Comm. $1981,912$.

22. Duddeck, H.; Dietrich, W. Structural Elucidation by Modern NMR; Springer-Verlag: New York, 1989, p 87.

23. Pattabhi, V.; Damodharan, L. unpublished results. 